\title{
Masyarakat Adat Balai Kiyu : Menghadapi Ancaman Eksistensi di Tanah Sendiri
}

\author{
Dimas Asto Aji An'Amta ${ }^{1}$, Ismar Hamid, Muhammad Luthfi Fahrizan \\ Universitas Lambung Mangkurat
}

\begin{abstract}
The Balai Kiyu Indigenous People are the Dayak indigenous people who have long occupied the Meratus mountain region in South Kalimantan. These indigenous people have problems that will threaten their existence. The problem is not internal, but external parties overshadowing communal well-being. This study aims to analyze the threats that will be faced by the Balai Kiyu Indigenous Peoples to their existence and is expected to represent the threats that will be faced by indigenous peoples along the Meratus mountains. Based on the research results obtained, the threat to the existence of the Indigenous Peoples Kiyu Centers among them is, first, the boundaries of indigenous territories so far that has not been authorized by the regional or central government, making them very vulnerable communities. Secondly, the Omnibus Law Bill on the Labor Copyright Act will clarify that indigenous peoples in the future will only be named, because of the loss of communal ownership rights so far.
\end{abstract}

Keywords: Indigenous Peoples, Existence, Omnibus Law, Welfare, Marginality

\begin{abstract}
Abstrak
Masyarakat Adat Balai Kiyu adalah masyarakat adat Dayak yang sudah lama menempati daerah pegunungan Meratus yang ada di Kalimantan Selatan. Masyarakat adat ini memiliki permasalahan yang akan mengancam eksistensi mereka. Permasalahan tersebut tidak berasal dari internal, namun pihak eksternal yang menjadi bayang-banyang terhadap kesejahteraan secara komunal. Penelitian ini bertujuan menganalisis ancaman yang akan dihadapi Masyarakat Adat Balai Kiyu terhadap eksistensi mereka kedepannya, dan diharapkan merepresentasikan ancaman yang akan dihadapi masyarakat adat disepanjang pegunungan Meratus. Pada hasil penelitian yang didapat, bahwa ancaman terhadap eksistensi Masyarakat Adat Balai Kiyu diantaranya pertama, batas wilayah adat selama ini belum dilegitimasi oleh pemerintah daerah maupun pusat menjadikan mereka masyarakat yang sangat rentan. Kedua, RUU Omnibus Law tentang Undang-Undang Cipta Kerja akan semakin memperjelas bahwa masyarakat adat kedepannya hanya akan menjadi sebuah nama, dikarenakan hilangnya hak kepemilikan komunal selama ini.
\end{abstract}

Kata Kunci : Masyarakat Adat, Eksistensi, Omnibus Law, Kesejahteraan, Marginalitas

\footnotetext{
${ }^{1}$ dimas.a@ulm.ac.id
} 


\section{Pendahuluan}

Pegunungan Meratus merupakan tembok terakhir untuk tetap melestarikan kekayaan alam yang masih tersisa di Kalimantan Selatan. Nuansa alam yang masih tetap dijaga dan dilestarikan oleh masyarakat adat dayak di sepanjang pegunungan Meratus menjadi tugas penting dalam interaksi mereka dengan alam. Mata pecaharian yang masih menggunakan ladang berpindah merupakan aktivitas kehidupan sosial ekonomi yang utama didalam memenuhi kebutuhan hidup.

Berladang atau menanam padi merupakan pemenuhan kebutuhan dasar hidup masyarakat adat Dayak sebagai konsumsi pokok mereka. Sistem perladangan berpindah yang selama ini berada di lereng pegunungan merupakan bentuk kearifal lokal dalam bercocok tanam. Menurut peneliti Balai Arkeologi Kalimantan Selatan Ida Bagus Putu Prajna Yogi (2018), keberlangsungan sistem berladang dengan memperhatikan keseimbangan lingkungan dimasyarakat adat Dayak disebabkan oleh beberpa faktor, yaitu; (1) ketergantungan masyarakat Dayak terhadap kebutuhan karbohidrat yang bersumber dari makanan padi, (2) teknologi bercocok tanam padi gunung telah diturunkan secara turun-temurun oleh nenek moyang mereka di seluruh pulau Kalimantan, (3) ketersediaan lahan yang memungkinakan di pedalaman pulau Kalimantan, (4) Kepercayaan masyarakat Dayak dengan tanaman padi sangat erat dalam aturan religi mereka, dan hampir semua religi dan upacara mereka selalu ada hubungannya dengan pertanian dan tanaman padi, (5) hampir sebagian besar masyarakat Dayak di Kalimantan tidak mengenal sistem persawahan irigasi.

Keberlangsungan sistem perladangan tersebut secara langsung juga menegaskan akan batas-batas kepemilikan lahan antar individu, maupun kepada masyarakat diluar dari komunal adat mereka. Setiap kepala keluarga memiliki lahan mereka masing-masing untuk memenuhi kebutuhan dasar hidup. Keberadaan lahan tersebut ada yang jauh dari pemukiman tempat tinggal mereka dan ada yang berdekatan dari pemukiman. Pemilikan lahan selama ini merupakan warisan dari nenek moyang yang sudah ditentukan batas-batasnya berdasarkan kesepakatan pendahulunya. Batas lahan selama ini berbeda dengan masyarakat modern pada umumnya yang menggunakan patok buatan sebagai legitimasi hak kepemilikan. 
Mereka menggunakan batas lahan kepemilikan secara alami berdasarkan pohon ataupun batu besar sebagai kesepakatan yang dilakukan oleh pendahulunya.

Pada penelitian yang dilakukan oleh Ahmad Rafiq (2013), dimana orang Dayak apabila mengaji sebuah ajaran, sekali melakukan selamatan, langsung hafal. Hal inilah yang membuat setiap adat istiadat dan segala norma yang berlaku pada masyarakat dayak tidak tertulis dalam sebuah kitab atau buku, melainkan dalam ingatan mereka. Karakter masyarakat adat Dayak yang memiliki tradisi mewarisi segala tradisinya secara lisan, tentu akan mengancam keberlangsungan setiap batas lahan secara alami pada masing-masing keluarga dan tentunya juga terhadap wilayah komunal mereka selama ini.

Keberadaan masyarakat adat akan semakin terpinggirkan dengan adanya rencana pemerintah dalam mengeluarkan pengganti undang-undang yang tumpang tindih. Omnibuslaw sebagai bentuk rencana pengganti undang-undang tumpang tindih membuat masyarakat adat semakin terancam dan terpinggirkan dari eksistensinya di nusantara. Batas-batas wilayah yang dimiliki dan diakui berdasarkan konsensus secara internal dimasyarkat adat dayak dan eksternal dari pemerintah daerah akan tersapu oleh kewenangan pemerintah pusat.

Ancaman tersebut direspon oleh Fraksi Rakyat Indonesia dengan mengeluarkan 12 alasan menolak Omnibus Law RUU cilaka pada Kertas Oposisi yang diupload Indonesia For Global Justice (IGJ) pada laman situs resminya januari 2020. Poin pertama yang disebutkan pada Kertas Oposisi tersebut adalah bahwa RUU Cilaka melegitimasi investasi perusak lingkungan, mengabaikan investasi rakyat dan masyarakat adat yang lebih ramah lingkungan dan menyejahterakan. Hal ini akan menjadikan masyarakat adat semakin termarginalkan dan memperbesar angka kemiskinan.

Menurut Suharto (2014) Ada tiga kategori kemiskinan yang menjadi pusat perhatian dalam kajian kemiskinan yaitu Destitute, Poor, Vulnerable Group. Kategori masyarkat adat dayak masuk pada Vulnerable Group, dimana masyarakat dalam golongan ini dapat dikatakan bebas dari kemiskinan, pendapatannya berada sedikit diatas garis kemiskinan dengan demikian kelompok ini dapat dikatakan memiliki kelayakan hidup yang relatif lebih baik dari pada kelompok destitute 
maupun poor. Tetapi kelompok ini sebenarnya sangat dekat dengan kemiskinan "near poor". Dalam kategori ini masyarakat rentan dianggap sangat mudah sekali berpindah status atau keadaan dari rentan menjadi miskin dan bahkan sangat miskin (destitute). Vulnerable Group yang dimaksudkan kepada masyarakat adat Dayak sangat beralasan. Hal itu mengingat alam dan lingkungan mereka tinggal sebagai penyangga keberlangsungan hidup mereka selama ini. Merusak alam dan lingkungan bagi mereka sama dengan membunuh keluarga dan komunitas masyarakat Adat dayak.

Ketidakberdayaan ini menegaskan bahwa masih sangat kuatnya marginalisasi terhadap masyarakat adat Balai Kiyu. Pada definisinya marginalitas adalah posisi seseorang yang berada diujung tanduk, dimana pada posisi itu mencegah akses mereka terhadap sumber daya dan peluang, kebebasan memilih dan pengembangan kemampuan pribadi. Diasingkan, tidak hanya dari pengembangan diri tetapi juga dari berbagai dimensi lain dari kemajuan masyarakat, merupakan indikasi bahwa orang yang sangat miskin berada di pinggiran masyarakat dan dalam banyak kasus marginalitas adalah sumber utama kemiskinan (Braun dalam Gatzweiler, 2009).

Frans W. Gatzweiler mendefinisikan marginalisasi sebagai suatu posisi dan kondisi yang tidak disengaja dari individu atau kelompok yang berada di pinggir suatu sistem sosial, politik, ekonomi, ekologi dan bio-fisik sistem, mencegah mereka dari akses pada sumber daya, aset, layanan, membatasi kebebasan memilih, serta mencegah perkembangan kemampuan (Gatzweiler, 2011:3).

Ancaman marginalisasi yang dihadapi masyarakat adat dayak di sepanjang pegunungan meratus sangat menarik untuk dikaji lebih dalam sebagai masyarakat yang sudah ada sebelum Republik ini berdiri. Permasalahan yang menghampiri mereka selama ini terjadi bukan dari internal komunal mereka. Melainkan dari faktor eksternal yang membuat mereka harus mempertahankan dan memperjuangkan yang merupakan hak mereka sebagai masyarakat adat. Tulisan ini menggali ancaman marginalisasi yang akan dihadapi oleh masyarakat Adat Balai Kiyu dalam mempertahankan eksistensi komunitas mereka. 


\section{Metode Penelitian}

Jenis penelitian yang digunakan oleh penulis pada penelitian ini adalah penelitan kualitatif dengan menggunakan metode deskriptif analitik. Menurut Agus Salim (2006) penelitian merupakan suatu metode berganda dalam fokus, yang melibatkan pendekatan interpretatif dan wajar terhadap setiap pokok persoalan yang dikajinya. Artinya metode penelitian kualitatif dilihat berdasarkan fenomena maupun keadaan sebenarnya yang kemudian ditafsirkan oleh kebanyakan orang pada fenomena tersebut. Penelitian diawali dengan mengidentifikasi berbagai masalah sosial dan eknomi Masyarakat pegunungan meratus terutama di Desa Hinas Kiri.

Penelitian ini dilakukan pada bulan Maret 2019 di sekitar Balai Kiyu yang terletak di Desa Hinas Kiri Kecamatan Batang Alai Timur Kabupaten Hulu Sungai Tengah, Kalimantan Selatan. Pemilihan Balai Kiyu diharapkan dapat merepresentasikan permasalahan diseluruh masyarakat Adat Dayak yang ada disepanjang bantaran pegunungan Meratus. Kegiatan ini dilakukan melalui studi pustaka, observasi lapangan, serta trianggulasi sebagai validitas data dalam menggali informasi dari para informan.

Pemilihan informan pada penelitian ini menggunakan tekhnik purposive sampling. Dimana pemilihan informan kunci atau yang dianggap paling mengetahui tentang tempat penelitian. Namun ditengah proses penelitian peneliti juga menggunakan snowball sampling disaat informan kunci merekomendasikan informan lainnya ketika ada pertanyaan yang dianggap belum bisa terjawab oleh informan sebelumnya.

Penyajian data pada tulisan ini dimulai dengan tradisi masyarakat adat Balai Kiyu dalam menerjemahkan batas kepemilikan lahan. Kemudian dihubungkan dengan RUU Omnibus Law yang akan semakin memarginalkan masyarakat adat Balai Kiyu. Selanjutnya dianalisis terkait batas lahan secara alami dengan RUU Omnibus Law dengan marginalisasi yang dilakukan oleh pemerintah terhadap masyarakat adat Balai Kiyu. 


\section{Hasil dan Pembahasan}

\section{Batas Wilayah, Legitimasi Eksistensi}

Aliansi Masyarakat Adat Nasional (AMAN) merupakan wadah yang selama ini memperjuangkan setiap hak dan kepentingan bersama mereka. Hak dan kepentingan yang tidak terakomodasi oleh pemerintah selalu diperjuangkan dalam hal mewujudkan keadilan sosial yang merata pada setiap sendi bangsa ini. Perjuangan untuk mendapatkan hak-hak masyarakat adat sebagai rakyat pada republik ini haruslah dimulai dengan memberikan pengakuan atas wilayah komunal mereka.

Pengakuan tersebut setidaknya dalam bentuk legitimasi yang jelas dan sinkronasasi antara pemerintah pusat, daerah dan masyarakat adat terhadap wilayah yang diklaim sebagai warisan leluhur. Sinkronisasi dilakukan agar tidak adanya tumpang tindih yang terjadi antara wilayah adat dan pihak eksternal komunal mereka. Tumpang tindih dalam bentuk akuisisi kepemilikan lahan antara masyarakat adat Dayak dengan pihak lain pernah terjadi pada tahun 2017 di Desa Kampung Baru, Kabupaten Tanah Bumbu Kalimatan Selatan yang masih masuk dalam bentangan pegunungan Meratus. Warga yang mendapatkan statusnya sebagai tersangka dikenakan pelanggaran Pasal 50 ayat 3 huruf a UU No. 41/1999 tentang Kehutanan yang berbunyi "setiap orang dilarang mengerjakan dan atau menggunakan dan atau menduduki kawasan hutan secara tidak sah". Selain itu juga pada pasal 94 ayat 1 huruf a dan b junto pasal 19 huruf a dan c UU No. 18/2013 tentang $\mathrm{P} 3 \mathrm{H}$, yang isinya dengan sengaja menyuruh, mengorganisasi, menggerakan, melakukan pemufakatan jahat untuk melakukan penggunaan kawasan hutan secara tidak sah

Pelanggaran tersebut terjadi dikarenakan salah satu masyarakat adat mengerjakan lahan yang sudah dimiliki pihak lain secara legal berdasarkan hukum negara. Padahal secara personal maupun komunal, masyarakat adat tersebut mengerjakan dan menggunakan lahan sudah puluhan tahun sebelum republik ini berdiri. Adanya penetapan status tersangka terhadap salah satu diantara mereka, membuat warga seolah tidak berdaya terhadap apa yang dimiliki atas kepemilikan wilayah adat selama ini. Kasus ini secara tidak langsung memberikan isyarat kepada 
masyarakat adat lainnya, bahwa wilayah mereka harus di akuisisi berdasarkan hukum negara. Termasuk sepanjang pegunungan meratus yang menjadi tempat masyarakat adat Dayak tinggal.

Kondisi tersebut sama dengan wilayah yang dikerjakan dan diakui oleh masyarakat adat Balai Kiyu. Mereka hanya mengerjakan sesuai dengan kepemilikan keluarga mereka. Uniknya mereka tidak melakukan pembagian lahan berdasarkan jumlah saudara dalam keluarga, tetapi mengakui lahan dengan memanfaatkannya semampu mereka. Seperti pada wawancara dengan kepala adat "Dangsanak ada empat, inya kada kaya diperkotaan pang balum, mun diperkotaan kan dibagi berapa dangsanak kan dibagi tanahnya per kavingkah, belum ada pang kami dibagi-bagi karena sama-sama mengelola, menjaga, menggawi, sama-sama memelihara. Sistem pinjam pakai bisa, betanam besamaan tapi hasilnya masing-masing. Misalnya dapat banyak kawa dijual, masing-masing itu kawa menjual

Masyarakat adat Dayak disepanjang pegunungan Meratus mempunyai permasalahan yang sama kedepannya jika tidak dilakukan legalitas kepemilikan wilayah. Melihat selama ini mereka hanya mengerjakan lahan berasarkan warisan secara lisan dari orang tuanya. Namun hal itu sepertinya masih dibiarkan berjalan apa adanya dari ketua adat Desa Kiyu saat diwawancarai. Pada wawancara tentang hak dan kepemilikan lahan selama ini masih dalam batas kesepatan komunal. Menurut ketua adat "sertifikat tanah yang anggit Jokowi, SKT kah tu ngarannya. SKT ni aturan pemerintah amun aturan kami ni kadada SKTnya . amun dijual akad bisa, misalnya aku sanda tapikan kaina ditabusi itu bisa. Amun dijual jadinya mati makanya kaina ujarku". Menurut beliau di wilayah ini tidak ada namanya SKT yang memberikan legalitas berdasarkan hukum negara tentang pememilikan pribadi tanah. Jika ingin menjual lahan perkebunan cukup menggunakan akad atau persetujuan antar pembeli. Namun mereka tidak mengenal jual beli melainkan memberikan pinjaman dengan jaminan lahan yang dimiliki (digadaikan). Hal itu menurutnya untuk menjaga tanah warisan leluhur. Lahan yang digadaikan bukan berupa lahan yang mati atau tidak produktif, namun lahan yang sudah ditanami yang memiliki nilai komoditas. 
Lahan bernilai secara ekonomis bagi mereka adalah lahan yang sudah ditumbuhi tanaman produktif siap konsumsi maupun dijual hasilnya. Hal itu disampaikan saat wawancara dengan warga Desa Balai Kiyu bernama saudara Rusmin, mengatakan "ketika terjadi jual beli kami hanya menjual kabunnya haja kalau tanahnya kada masuk hitungan karna kada berharga yang berharga tuh cuma isinya haja, kalau bajual tanah kosong kadada pang lagi”. Menurutnya selama ini tidak pernah terjadi jual beli lahan secara hukum negara seperti yang terjadi di perkotaan, melainkan hanya sewa dan pinjam lahan.

Menjadi sangat penting tentang pengakuan yang harus didapat masyarakat adat Dayak di Desa Balai Kiyu adalah tentang batas wilayah yang diakui secara administratif negara. Pengakuan yang seharusnya sudah dimiliki mereka sebagai penghargaan atas jasa dalam menjaga aset negara dari bentuk penjarahan secara illegal pada sumber daya alamnya dan kearifan lokal yang merupakan harta karun jati diri bangsa. Kearifan lokal yang mereka miliki tidak hanya berlaku bagi internal komunal mereka, namun juga eksternal mereka yang ingin melakukan ekploitasi alam selama masih dalam batas wilayah adat. Segala sanksi adat yang dijalankan dalam memelihara keseimbangan alam tidak akan efektif jika negara tidak ikut berkontribusi.

Legitimasi batas wilayah yang diinginkan oleh masyarakat Adat Dayak bukan dalam bentuk program Perndaftaran Tanah Sistematis Lengkap (PTSL) yang selama ini digalakkan melalui Kementrian ATR/BPN. Melainkan dalam bentuk pengakuan secara administratif keseluruhan wilayah Adat Balai Kiyu. Penolakan terhadap program PTSL atau yang lebih dikenal dengan sertifikasi tanah menurut ketua Adat Balai Kiyu akan mengancam eksistensi mereka secara perlahan kedepannya. Menurut beliau "Apabila hancur wilayah adat hancur jua juriyatnya itu jua yang dipertahankan. Tahu am mun generasi muda kaina, ada ai yang handak menjual kabun tapi apabila handak menjual tanah mohon maaf jarku kita belum pernah menjual tanah. Mun menjual jangan sampai keluar artinya tawarkan dikampung dahulu, apabila di kampung ni menolak atau duitnya kadada keluar ha. Cuman bila menjual keluar dipikirakan anak cucu kedepannya kaina. 
Pada wawancara tersebut beliau mengatakan jika tanah adat ini hancur maka hancur juga keturunan atau generasi selanjutnya, maka pesan dari beliau adalah harus tetap dipertahankan. Namun ketua adat juga tidak menampik bagaimana kedepannya yang jika dipegang oleh generasi muda. Mungkin akan ada saja yang ingin menjual kebun, tetapi harapan beliau jika tetap ingin menjual tanah usahakan jangan sampai menawarkannya keluar dari adat, artinya ditawarkan dahulu secara internal masyarakat adat, apabila masyarakat menolak ataupun tidak mempunyai uang maka silahkan ditawarkan ke keluar dari adat Balai Kiyu. Tetapi pesannya juga tetap harus dipikirkan secara matang apabila menjual keluar dari komunal, karena yang dipertaruhkan dan dipikirkan adalah generasi yang akan datang tentang eksistensi masyarakat adat Balai Kiyu..

Penolakan terhadap tawaran program PTSL juga diungkapkan salah satu warga Adat Balai Kiyu. Bapak Rusmin mengatakan "dahulu ada pang suah datang kesini yang dari program Jokowi, artinya kan di berikan sertifikat tanah siapa yang handak meulah gratis asal bujur-bujur tanah seurang. Tapi dari kami menyangkal itu semalam termasuk aku jua, kalau seperti ini kaina akan hilang sistem kepercayaan hak waris lawan artinya tanah kepemilikan Bersama. Menurut bapak Rusmin sertifikat secara legal formal akan menguatkan kepemilikan atas hak lahannya. Namun kepemilikan tersebut bersifat personal yang memungkinkan akan memecah arti kepemilikan bersama. Artinya jika sertifikat diberikan kepada warga yang memiliki hak waris atas lahan tersebut, lambat laun keberadaan wilayah adat Balai Kiyu akan tergadaikan kepada pihak eksternal komunal mereka.

Bagan 1. Perbedaan konsep kepemilikan

\begin{tabular}{|c|c|c|}
\hline $\begin{array}{l}\text { Dikelola } \\
\text { secara turun } \\
\text { menurun }\end{array}$ & \multirow{5}{*}{\begin{tabular}{|c|}
$\begin{array}{c}\text { Wilayah } \\
\text { Berdasarkan } \\
\text { Hukum }\end{array}$ \\
vS \\
$\begin{array}{c}\text { Wilayah } \\
\text { Berdasarkan } \\
\text { Adat }\end{array}$ \\
\end{tabular}} & \multirow{2}{*}{$\begin{array}{c}\text { Berdasarkan } \\
\text { Undang-Undang } \\
\text { dan Perda, }\end{array}$} \\
\hline $\begin{array}{c}\text { Diakui } \\
\text { secara lisan }\end{array}$ & & \\
\hline Batas wilayah & & di BP \\
\hline $\begin{array}{l}\text { menggunakan } \\
\text { media alam }\end{array}$ & & \\
\hline $\begin{array}{l}\text { Tanpa } \\
\text { sertifikat dari } \\
\text { pemerintah }\end{array}$ & & $\begin{array}{c}\text { yang jelas } \\
\text { seperti sertifikat } \\
\text { dan lainnya }\end{array}$ \\
\hline
\end{tabular}


Melihat pada bagan 1 yang menegaskan bahwa perbedaan konsep kepemilikan wilayah sangat berbeda antara adat dengan hukum negara. Oleh karena itu program PTSL tentu tidak sesuai dengan kearifan lokal yang dimiliki masyarakat adat Balai Kiyu. Mereka juga tidak memerlukan sertifikasi tanah jika dilakukan atas kepemilikan personal. Kebutuhan yang penting tentang batas wilayah mereka adalah keseluruhan wilayah adat yang diakui secara legal formal bersadarkan aturan negara untuk keberlanjutan hidup mereka. Karena mereka selama ini tidak mempunyai dokumen disetiap batas wilayahnya, yang masyarakat Adat Balai Kiyu pahami adalah batas wilayah berdasarkan alam seperti batu besar, pohon, sungai dan tebing disepakati bersama secara lisan dari pendahulu mereka.

\section{Omnibus Law Jawaban Atas Penundaan RUU Masyarakat Adat}

Undang-Undang sebagai regulasi yang memayungi sekaligus menjebatani setiap hak dan kewajiban warganya semestinya tidak saling tumpang tindih. Namun pada kenyataannya masih banyak setiap peraturan maupun perundang-undangan yang masih saling bertabrakan dan terkesan tidak konsisten. Menurut data Pusat Studi Hukum dan Kebijakan Indonesia (PSHK) memperlihatkan bahwa dalam rentang waktu antara 2014 hingga Oktober 2018 saja, telah terbit 8.945 regulasi. Pada rinciannya, terdapat 107 Undang-Undang, 452 Peraturan Pemerintah, 765 Peraturan Presiden, dan 7.621 Peraturan Menteri.

Banyaknya peraturan yang keluar dari rentang waktu tersebut membuat pemerintah beralasan untuk merevisi undang-undang yang saling tumpang tindih. Perevisian dilakukan dengan cara mengeluarkan produk baru bagi sistem hukum di Indonesia yang bernama Ominibus Law. Produk perudangan baru tersebut membuat banyaknya perundangan yang ada akan gugur secara otomatis dan tergantikan dengan Omnibus Law. Ada dua Undang-Undang besar yang menggantikan peraturan maupun perundangan sebelumnya, yaitu Undang-Undang Cipta Lapangan Kerja dan Unndang-Undang Pemberdayaan UMKM. Namun dalam kedua perundangan besar tersebut yang akan menjadi permasalahan bagi masyarakat Adat Balai Kiyu adalah UU tentang Cipta Lapangan Kerja. 
Undang-Undang tersebut dinilai oleh komunitas Aliansi Masyarakat Adat Nasional (AMAN) merasa dirugikan dan akan menjadi ancaman terhadap eksistensi masyarakat adat secara nasional. Pada laman resmi AMAN yaitu aman.or.id merilis Catatan Akhir Tahun (Catahu) 2019 memberikan catatan penting tetang Omnibus Law. Catatan tersebut memperingatkan bahwa berbagai kasus perampasan wilayah adat, kekerasan dan kriminalisasi sebagaimana telah diuraikan sebelumnya terjadi dalam situasi dimana belum ada gagasan pembentukan Ominibus Law. Artinya, tanpa Omnibus Law sekalipun pada dasarnya investasi di atas wilayah-wilayah adat telah mengalir deras tak terbendung. Tanpa Omnibus Law, Pemerintah bahkan pernah dengan enteng mengubah larangan menambang secara terbuka di hutan lindung hanya untuk memfasilitasi 13 perusahaan yang bergerak di bidang pertambangan melalui Peraturan Pemerintah Pengganti Undang-Undang/PERPPU No. 1 tahun 2004.

Masyarakat adat dalam hal ini menjadi semakin termarginalkan dengan adanya konsep Omnibus Lam. Bahkan semakin membuka lebar dalam menambah kemiskinan yang termasuk dalam kategori Vulnerable Group, jika produk Omnibuslaw terutama Undang-Undang Cipta Lapangan Kerja terus berlanjut. Menurut Soeharto (2014) dimana masyarakat dalam golongan ini dapat dikatakan bebas dari kemiskinan, pendapatannya berada sedikit diatas garis kemiskinan dengan demikian kelompok ini dapat dikatakan memiliki kelayakan hidup yang reltif lebih baik dari pada kelompok destitute maupun poor. Tetapi kelompok ini sebenarnya sangat dekat dengan kemiskinan "near poor". Kategori ini membuat masyarkat adat terutama pada Balai Kiyu harus mempertahankan dan memperjuangkan apa yang sudah menjadi ketentuan adat, agar tidak jatuh kepada kategori poor atu destitute.

Perubahan kategori tersebut akan memicu terjadinya konflik dikarenakan menurunya tingkat kesejahteraan berdasarkan pemenuhan kebutuhan dasar yang ada pada mereka saat ini. Penurunan kebutuhan dasar yang selama ini ada dan didapat secara gratis tentu akan hilang seiring tergesernya masyarakat adat Balai Kiyu dari tanah mereka. Jika bercermin pada penelitian yang dilakukan oleh R. Yando Zakaria, dkk tahun 2017 yang berjudul Studi Biaya Konflik Tanah Dan Sumber 
Daya Alam Dari Perspektif Masyarakat memberikan hasil yang mengejutkan. Hasil kajian menujukkan rata-rata sebesar $36.79 \%$ dari nilai komoditas konsumsi masyarakat saat ini bisa didapat tanpa harus membeli di masa lalu. Dampak tersebut tertinggi terjadi di wilayah Kalimantan Barat yakni sebenar $41.65 \%$, dikiuti oleh Kalimantan Timur sebesar $35.82 \%$ dan jambi sebesar $29.58 \%$. Artinya dalam ketidakjelasan terhadap kepemilikan lahan secara hukum negara oleh masyarakat adat akan menurunkan tingkat kesejahteraan masyarakat yang berkonflik dengan menghilangkan kebutuhan dasar yang saat ini ada tanpa membeli. Tentu hal ini akan menjadi bayang-bayang kedepannya bagi masyarakat adat Balai Kiyu dalam menghadapi kemungkinan terjadinya konflik dengan pihak eksternal.

\section{Marginalisasi Masyarakat Adat Balai Kiyu, Merampas Kesejahteraan}

\section{Komunal}

Abu-abunya batas wilayah yang diakui oleh masyarakat adat Balai Kiyu dari kaca mata pemerintah pusat menegaskan tentang masih belum diakui sepenuhnya keberadaan masyarakat adat ditanah air. Jika RUU Omnibus Law diresmikan oleh pemerintah maka batas-batas yang dimiliki oleh masyarakat adat selama ini akan terenggut oleh pihak ekternal yang memiliki kepentingan diatasnya. Hal ini akan membuat masyarakat adat menjadi pada posisi sulit mendapatkan akses sumber daya alam yang selama ini menghidupi mereka. Artinya mereka telah termarginalkan oleh negara yang seharusnya melindungi keberadaan masyarakat adat.

Pada definisi yang dikemukakan oleh Von Braun (dalam Gatzweiler, 2011) marginalitas adalah posisi seseorang yang berada diujung tanduk, dimana pada posisi itu mencegah akses mereka terhadap sumber daya dan peluang, kebebasan memilih dan pengembangan kemampuan pribadi. RUU Omnibus Law menihilkan masyarakat adat pada segala aspeknya. Mulai dari hak atas pengelolaan dan pemanfaatan alam dalam pemenuhan kebutuhan hidupnya sampai kearifan lokal yang dimiliki. Memarginalkan masyarakat adat Balai Kiyu secara jelas memberikan ruang mereka untuk jatuh pada lubang kemiskinan. Menurut Von Braun marginalitas tidak hanya merenggut kebebasan tetapi juga diasingkan, tidak hanya 
dari pengembangan diri tetapi juga dari berbagai dimensi lain dari kemajuan masyarakat, merupakan indikasi bahwa orang yang sangat miskin berada di pinggiran masyarakat dan dalam banyak kasus marginalitas adalah sumber utama kemiskinan.

Sedangkan Frans W. Gatzweiler mendefinisikan marginalisasi sebagai suatu posisi dan kondisi yang tidak disengaja dari individu atau kelompok yang berada di pinggir suatu sistem sosial, politik, ekonomi, ekologi dan bio-fisik sistem, mencegah mereka dari akses pada sumber daya, aset, layanan, membatasi kebebasan memilih, serta mencegah mengembangkan kemampuan (Gatzweiler, 2011: 3). Gatzweiler memberikan definisi dengan dimensi yang luas terhadap dampak dari maginalitas yang didapat oleh individu maupun kelompok. Sangat jelas jika posisi masyarakat Adat Balai Kiyu pada RUU Omnibus Law akan semakin termarginalkan. Ditambah batas wilayah adat yang sampai detik ini belum ada kejelasan terhadap legalitas berdasarkan hukum negara. Sedangkan marginalisasi terhadap individu maupun kelompok itu sama dengan menjauhkan mereka dari kesejahteraan.

Kesejahteraan pada dasarnya sudah dimiliki oleh masyarakat adat Balai Kiyu dari hubungan harmonisnya dengan alam. Hubungan tersebut membuat mereka tidak menuntut kepada negara tentang hak mereka sebagai warga negara untuk memperoleh kesejahteraan berdasarkan Undang-Undang. Pada UndangUndang Nomor 11 Tahun 2009 tentang Kesejahteraan Sosial, Pasal 1 Ayat 1 "Kesejahteraan sosial ialah kondisi terpenuhinya kebutuhan material, spiritual, dan sosial warga negara agar dapat hidup layak dan mampu mengembangkan diri, sehingga dapat melaksanakan fungsi sosialnya. Kesejahteraan pada dasarnya sudah diatur dalam Undang-Undang untuk menjamin warganya mendapatkan penghidupan yang layak. Namun kesejahteraan yang seharusnya diberikan oleh negara malah sebaliknya akan diambil dari tangan mereka jika produk hukum Omnibus Law disahkan.

Bayangan masyarakat adat Balai Kiyu terhadap kesejahteraan dan eksistensi mereka akan terus berlanjut disaat enam janji Presiden Jokowi kepada masyarakat adat diseluruh nusantara belum terealisasikan. Enam janji yang dilontarkan saat 
berpasangan dengan Jusuf Kalla (dalam tempo.co.id) diantaranya adalah meninjau ulang dan menyesuaikan seluruh peraturan perundang-undangan terkait dengan Pengakuan, Penghormatan, Perlindungan dan Pemajuan Hak-Hak Masyarakat Adat, khususnya yang berkaitan dengan hak-hak atas sumber daya agraria sebagaimana yang diamanatkan dalam TAP MPR RI Nomor IX/MPR/2001 tentang Pembaruan Agraria dan Pengelolaan Sumber Daya Alam sesuai dengan norma-norma hukum sebagaimana yang telah ditetapkan dalam Putusan Mahkamah Konstitusi Nomor 35/PUU-X/2012.

\section{Kesimpulan}

Masyarakat adat Balai Kiyu merupakan komunitas yang sudah ada sebelum bangsa Indonesia berdiri. Pemanfaatan atas kekayaan alam yang dimanfaatkan berdasarkan kearifan lokal pada dasarnya hanya untuk memenuhi kebutuhan hidup dasar mereka. Pemanfaatan tersebut juga tidak akan dilakukan tanpa melakukan perhitungan terhadap dampak ekologis. Alam dan lingkungan sekitarnya akan selalu menjadi sahabat bagi mereka. Maka legitimasi atas wilayah adat yang selama ini menjadi pengidupan bagi komunal mereka sangat patut dimiliki sebagai bentuk penghargaan terhadap sumber daya alam yang dijaga mereka selama ini.

Namun dari penelitian ini legitimasi atas wilayah adat nampaknya akan semakin sulit didapat untuk kedepannya. Masyarakat adat terutama di Balai Kiyu akan termarginalkan oleh beberapa keaadaan yang mengancam eksistensi mereka. Pertama, batas wilayah yang selama ini masih belum diakui secara legal formal secara hukum negara akan mudah terjadinya konflik vertikal maupun horizontal. Kedua, rencana pemerintah dalam mengeluarkan RUU Omnibus Law Cipta Lapangan Kerja akan semakin mengancam keberadaan meraka, maka konflik vertikal semakin terbuka lebar jika Undang-Undang tersebut tetap diterbitkan. Artinya marginalisasi masyarakat adat Balai Kiyu dalam hal ini dilakukan oleh negara yang seharusnya memberikan ruang untuk mensejahterakan rakyatnya. 


\section{Daftar Pustaka}

Aman.or.id, "Pertahankan Wilayah Adat, Tokoh Masyarakat Adat Meratus ditangkap, 1 Maret 2020, http://www.aman.or.id/2017/02/pertahankanwilayah-adat-tokoh-masyarakat-adat-meratus-ditangkap/

Badan Pusat Statistik (BPS) Kalimantan Selatan. Kecamatan Batang Alai Timur Dalam Angka Tahun 2019

Catatan Akhir Tahun (Catahu) Tahun 2019 Aliansi Masyarakat Adat Nasional. Gatzweiler, F.W. Heike Boumuller, Christtine Ladenburger, dan Joachim von Braun. (2011). Marginality:Addressing the Root Causes of Extreme Poverty. Bonn: Center for Development Research, University of Bonn Geertz, Clifford. 1970. Agricultural Involution: The Process of Ecological Change in Indonesia. Berkeley and Los Angeles: University of California Press Igj.or.id, "12 alasan menolak omnibus Law RUU Cilaka, 13 Februari 2020, http://igj.or.id/wp-content/uploads/2020/01/12-ALASAN-MENOLAKOMNIBUS-LAW-RUU-CILAKA.pdf

Pshk.or.id, "Pernyataan sikap Pusat Studi Hukum dan Kebijakan Indonesia (PSHK) atas pidato visi Indonesia, 1 Maret 2020, https://pshk.or.id/publikasi/siaranpers/pernyataan-sikap-pusat-studi-hukum-dan-kebijakan-indonesia-pshkatas-pidato-visi-indonesia/

Rafiq, Ahmad. 2013. Relasi Dayak-Banjar Dalam Tutur Masyarakat Dayak Meratus. Al-Banjari. 12 (1), (117-146).

Salim, Agus. Teori dan Paradigma Penelitian Sosial. Yogyakarta: Tiara Wacana. Suharto, Edi. 2014. Membangun Masyarakat Memberdayakan Rakyat. Bandung:

Refika Aditama.

Tempo.co, "Aman Ingatkan 6 Janji Jokowi ke Masyarakat Adat Belum Terealisasi,

5 Maret 2020, https://Tekno.Tempo.Co/Read/1262297/Aman-Ingatkan-6Janji-Jokowi-Ke-Masyarakat-Adat-Belum-Terealisasi/Full\&View=Ok

Undang-Undang Nomor 11 Tahun 2009 tentang Kesejahteraan Sosial Undang-Undang Dasar Negara Republik Indonesia Tahun 1945

Undang-Undang No. 18/2013 tentang P3H, Undang-Undang No. 41/1999 tentang Kehutanan Yogi, Ida Bagus Putu Prajna. 2018. Padi Gunung Pada Masyarakat Dayak, Sebuah Budaya Bercocok Tanam Penutur Austronesia (Melalui Pendekatan Etnoarkeologi). Forum Arkeologi. 31 (1), (45 - 56)

Zakaria, Yando. R, dkk. 2017.Studi Biaya Konflik Tanah Dan Sumber Daya Alam Dari Perspektif Masyarakat. Conflict Resolution Unit (CRU). 